Decadal-Scale Analysis of Coastal Landslides Along the Big Sur Coast: Rates And Processes

U.S. Department of the Interior U.S. Geological Survey

Open-File Report 2005-1434

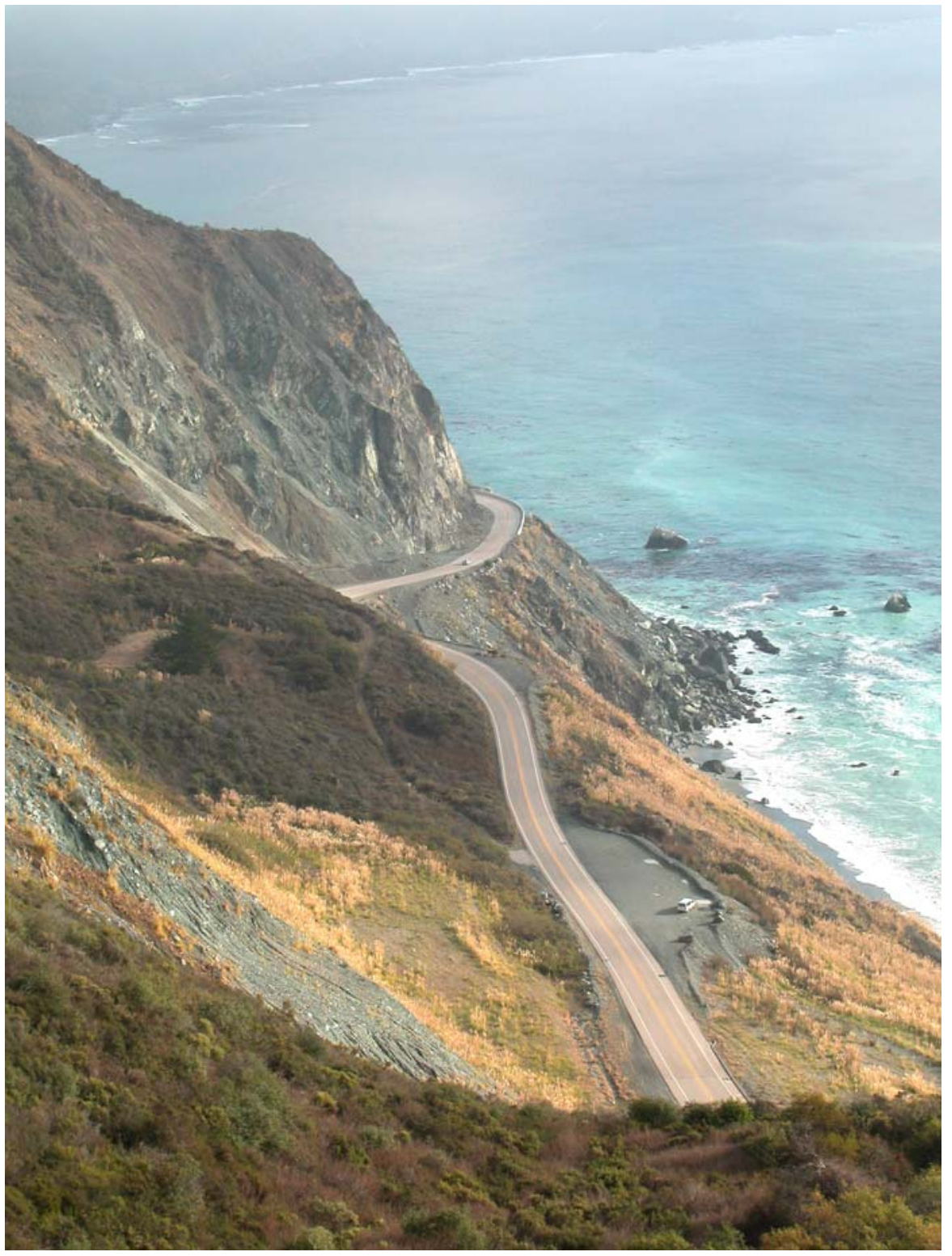




\section{Decadal-Scale Analysis of Coastal Landslides Along the Big Sur Coast: Rates and Processes}

By Cheryl J. Hapke, ${ }^{1}$ and Krystal R. Green ${ }^{1,2}$

Open-File Report 2005-1434

2005

Any use of trade, firm, or product names is for descriptive purposes only and does not imply endorsement by the U.S. Government.

\section{U.S. Department of The Interior}

U.S. Geological Survey

1 U.S. Geological Survey, Pacific Science Center, 400 Natural Bridges Drive, Santa Cruz, CA 95060.

2 Earth Science Department, University of California Santa Cruz, 1156 High St., Santa Cruz, CA 95064

\section{Cooperators}

California Department of Transportation, District 5 


\section{List of Figures}

Figure 1. Map showing location of the MBNMS and the Big Sur Coast in central California.

Figure 2. Graph showing the interim loss rate of material to the nearshore for each of the three landslide sites.

Figure 3. Oblique aerial photographs of the three study areas.

Figure 4. Loss/gain distribution maps for the three landslide sites showing the areas for each analysis period where there has been a loss or gain of material within the landslide complex.

\section{List of Tables}

Table 1. Statistics of the error in the grids used to conduct the analysis.

Table 2. Net loss, area and loss rate for each of the landslide sites.

\section{Additional Digital Information}

For additional information about the California Department of Transportation Big Sur Coast Highway Management Plan, see:

http://www.dot.ca.gov/dist05/projects/bigsur/

For an online PDF version of this report, please see:

http:// pubs.usgs.gov/of/2005/1434/

For more information on the U.S. Geological Survey Western Region's Coastal and Marine Geology Team, please see:

http://walrus.wr.usgs.gov/ 


\section{Introduction}

Landslides in the coastal mountains of Big Sur in Monterey and San Luis Obispo Counties are common, especially during the winter months. These frequent landslides regularly disrupt Coast Highway 1, by blocking the highway with boulders and/or debris, or undercutting the roadway. Historical documentation of landslide activity in this area indicates slide activity closed portions of the road prior to its completion in 1937 (JRP Historical Consulting Services, 2001). The California Department of Transportation (Caltrans) maintains the Coast Highway 1 corridor and recently established the Big Sur Coast Highway Management Plan (CHMP) to develop management practices that will best maintain the highway while minimizing impact on the nearshore environment of the Monterey Bay National Marine Sanctuary (MBNMS) just offshore (fig. 1). One issue of concern is that deposition of the landslide material in the MBNMS may have a negative impact on nearshore biological communities. While some deposition of material from landslides is natural, some of the road re-opening and slope stabilization practices generate additional material that also needs to be disposed of. In order to better understand the spatial and temporal distribution of sediment input from landslides along the Coast Highway 1 corridor, a study was conducted to measure the long-term volumetric sediment yield and the history of active slopes (Hapke, 2005; Hapke and others, 2004). While this study provided both Caltrans and the MBNMS with valuable data on the locations and amount of sediment yield, it provided little information on the processes and rates by which this material is delivered to the nearshore. Long-term input rates were calculated but because catastrophic movement on these large slides is highly episodic, the averaged rates provide little information as to how much material may be eroded or deposited during a given year or over the course of a decade.

The purpose of the present study is to document the rates and processes of landslide movement and sediment delivery along three specific landslides: Hurricane Point, Big SlidePitkins Curve, and Grayslip (fig. 2). The primary goals of the research are to quantify the shortterm (decadal) rate of movement of material within each of the landslide complexes, to analyze how the landslide evolves morphologically through time, and to produce decadal-scale maps of the distribution of losses and gains in the landslide to determine how much sediment is deposited into the MBNMS (or removed by trucking). 


\section{Study Area}

The Big Sur coastline is on the western side of the Coast Range, a northwest-trending mountain range that extends along the west coast from near Santa Barbara, CA to the Oregon border. The rocks exposed along the Big Sur coastline are a complex mixture of sheared and metamorphosed sedimentary and igneous rocks of the Late Jurassic to Miocene Franciscan Complex (Dibblee, 1974; Ross, 1976), and early Mesozoic plutonic and metamorphic rocks of the Sur Complex of Hall (1991).

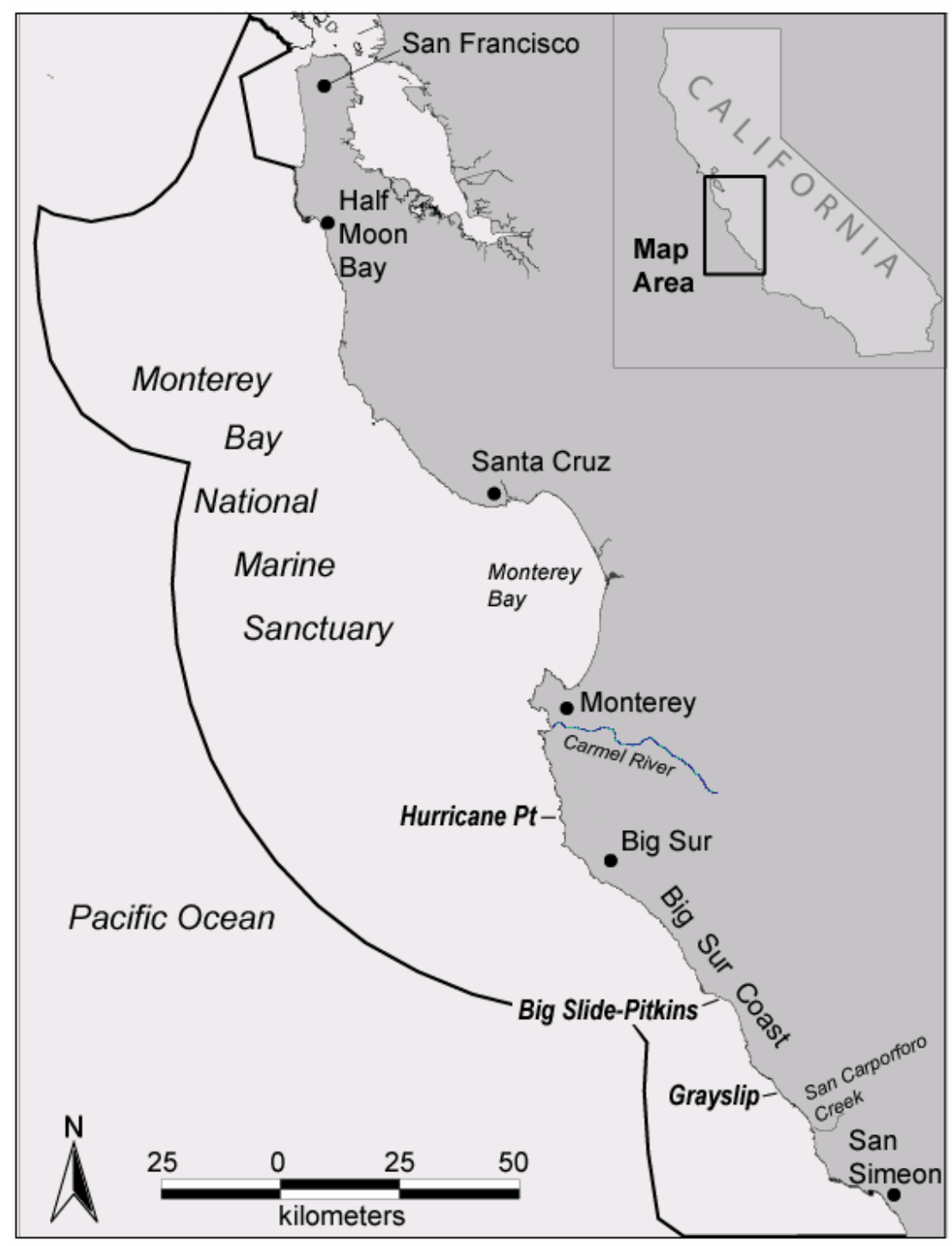

Figure 1. Map showing location of the MBNMS and the Big Sur coast in central California. The three study areas shown on the map correspond to the specific landslides: Hurricane Point, Big Slide/Pitkins Curve, and Grayslip. 
Undifferentiated metamorphic rocks and marbles of the Sur Complex of Hall (1991) (James and Mattinson, 1988) are exposed at Hurricane Point (fig. 1), along with Cretaceous sandstone, and sandstone and shale of the Miocene and Pliocene Pismo Formation (Hall, 1991).

Big Slide-Pitkins and Grayslip landslides (fig. 1) are within the Franciscan Complex, which includes metavolcanic rocks (greenstone), serpentinite, and interbedded, highly sheared argillite and greywacke (Bailey and others, 1964). Landslide deposits overlie these bedrock units over much of the Big Sur coast, including the three areas described in this report (Hall, 1991; Wills and others, 2001).

The rocks of the Franciscan Complex tend to be weaker than those of the Sur Complex of Hall (1991); the majority of the chronic landslides occur where Franciscan Complex rocks underlie the steep slopes. However, the lithology within the Franciscan Complex varies dramatically, and the softer, highly sheared rocks and mélange are more prone to landsliding whereas the various sedimentary strata and volcanic rocks form somewhat more stable slopes (Wills and others, 2001; Hapke, 2005).

\section{Methods}

Digital photogrammetry was used in this study to produce 3-dimensional Digital Terrain Models (DTMs) of each study area, for four dates (1976, 1986-87, 1993, and 2001). The DTMs were brought into a GIS, converted into a grid format, and subtracted from one another in order to map the changing distribution of material gains and losses within each landslide mass. In addition, volumes of each area were calculated and subtracted to yield a net volume change for each site for each time period.

The photographs were chosen for their coverage and scale; in order to maintain a pixel resolution of 0.50 meters or less, all imagery has a nominal scale of 1:12000, and was scanned at resolution of 22.5 microns (approximately $1200 \mathrm{dpi}$ ). Photographs were obtained as film diapositives to minimize errors associated with distorted media. We attempted to locate photographs that would allow us to extend the analysis further back in time (pre-1976); the oldest appropriate photography we found was flown in 1970. We were unable to obtain a reasonable root mean square error solution within the photogrammetric processing for the models from the 1970 photographs, and the subsequent DTMs contained obvious non-systematic errors. Therefore the 1970s data was not used in our final analysis. As a result, our analysis for each of the three sites includes a time-series change analysis for four dates. 

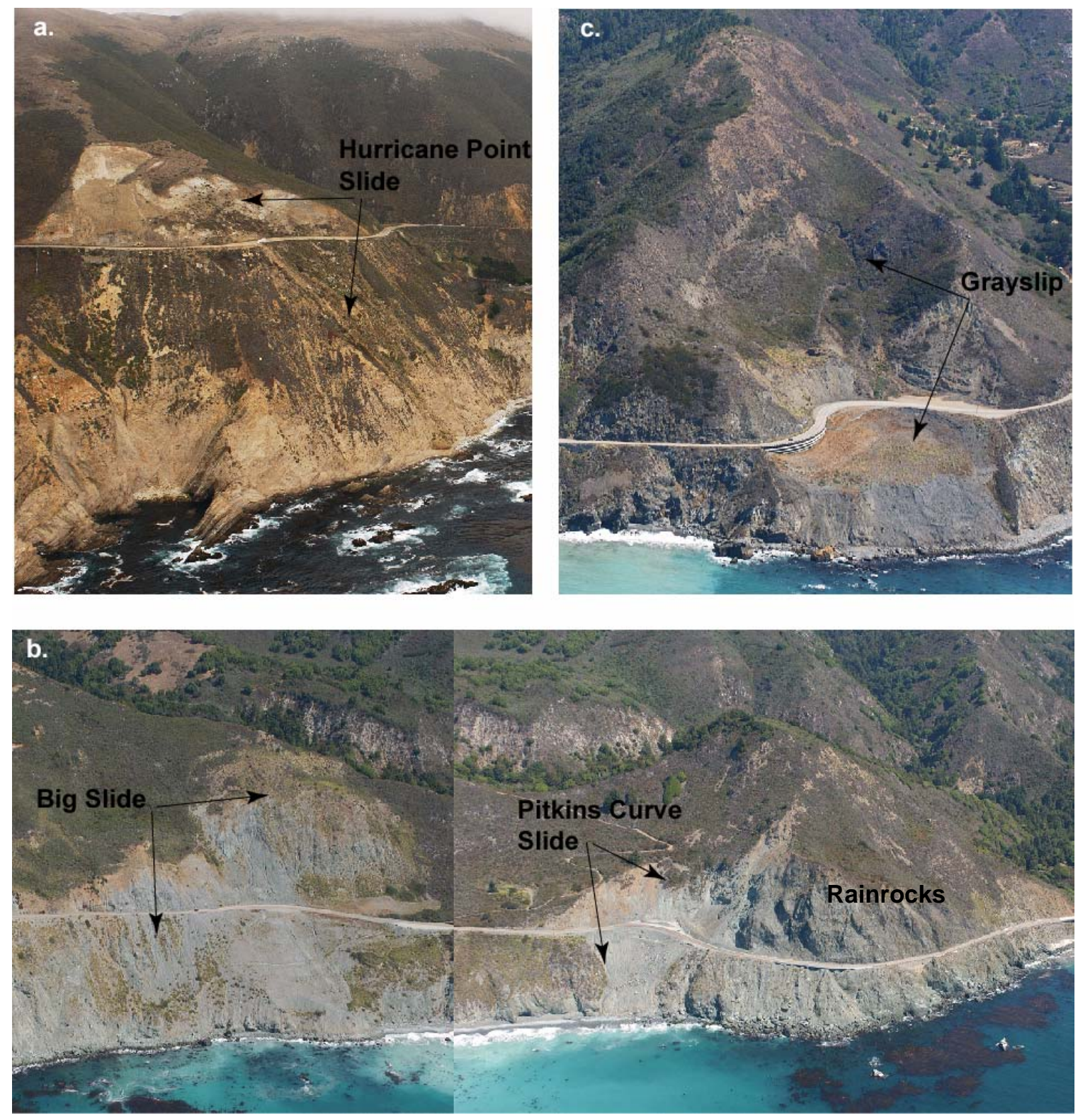

Figure 2. Oblique aerial photographs of the three study areas. A. Hurricane Point, B. Big Slide-Pitkins Curve, and C. Grayslip. Coast Highway 1 is the main road visible in each photo. Photographs copyright (C) 2002 Kenneth Adelman, California Coastal Records Project, www.californiacoastline.org.

The digital photogrammetry workflow used in this analysis is very similar to that outlined used by Hapke and others (2004), and will not be expanded in detail here. The primary difference is that the current analysis used surveyed ground control points and thus the resulting models are much more accurate than those created in the previous study. For each date and site, three photographs (two stereo-models) were used to create the terrain models of the landslide complexes and surrounding areas. For the ground control points, 5-6 points for each study area were identified on the 2001 photography and were surveyed in the field using a differential global positioning system (DGPS) in December 2003. The errors associated with these control data 
are sub-decimeter, and are incorporated into the overall model error analysis outlined below. In some cases, the surveyed ground control points could be located on the earlier photography. In general, the further back in time, the more difficult it becomes to locate the exact point.

Therefore, most of the control for photography pre-dating 2001 was derived from the most immediate, younger model. In other words, control for the 1993 photography was derived from the 2001 model, control for the 1986 was derived from 1993, and so on. Extrapolated control includes features such as road intersections, driveways, sidewalks and parking lots. Where no distinct cultural features exist, individual rocks in rock outcrops outside the landslide complex that appear to be stable in the period between photographs were used. Errors associated with the control extrapolation technique are detailed below.

The terrain models are generated with a nominal point spacing of $5 \mathrm{~m}$. However, because a triangulated irregular network (TIN) is being used, the point spacing varies as the TIN model is edited. Once the terrain models are generated, they are exported from the photogrammetry software as shapefiles. The shapefiles consist of both the original TIN points and breaklines that were added to the terrain models during the terrain editing process. In order to derive volumes and map the spatial distribution of topographic change, the terrain data must be converted into grid format. For this analysis, the cell size for all grids is $3 \mathrm{~m}$. In order to estimate the error (iterative error and manual edits) of the grids relative to the original data we compared the value of original TIN mass points to the cell value of the respective grid. The statistics of this grid error analysis are shown in Table I. While the maximum and minimum values are fairly high, these high values occur with low frequency. For all data analyses and calculations, we exclude data that is greater than 2 standard deviations of the grid error, and thus we are $95 \%$ confident that the data used for analysis represent actual change.

In addition to generating the topographic change maps, material volumes were quantified for each date for the landslide areas above and below the highway. This was done with the assumption that the majority of volume loss below the highway is due primarily to natural processes (waves, slumps, overland flow), while volume loss above the highway could be natural or induced by road maintenance and stabilization practices. The volumes for each surface model were calculated from a plane of $1.0 \mathrm{~m}(3.1 \mathrm{ft})$ above mean sea level to the road grade for the below-the-road volume, and from the road grade to the ridge top for the above-theroad volume calculation. The edges of the areas are defined by the morphology of the landslide complex in that they correspond to the extents of landmass movement (i.e. original active scarps). The same general area was used for all time periods but may change slightly if the topography changes. 
Table 1. Grid Error Statistics

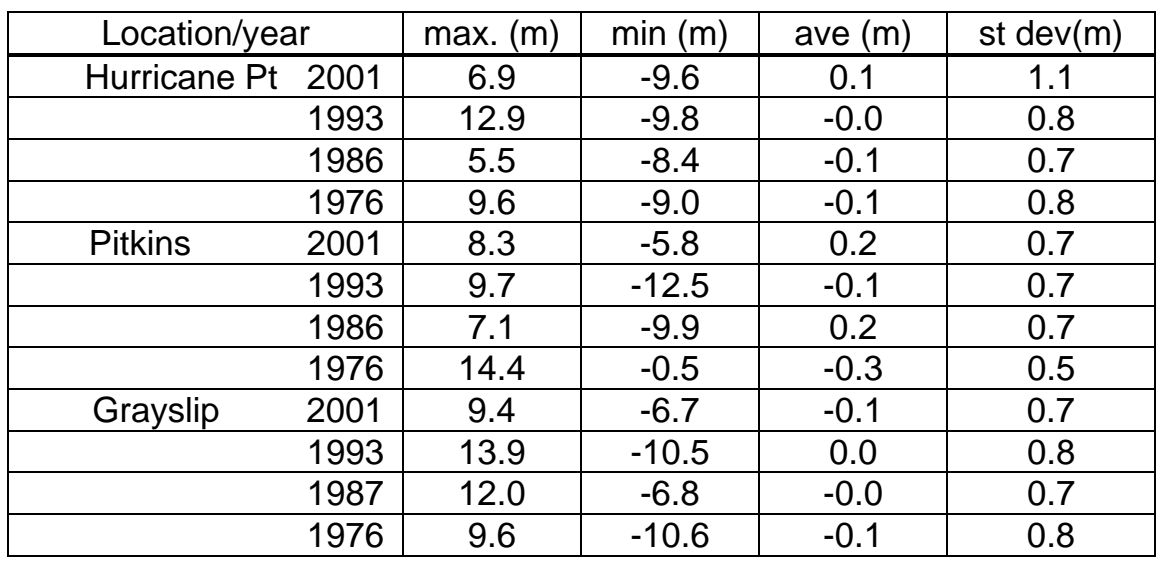

Since the grid error is removed from the data prior to volume change calculations, the remaining error associated with analysis includes errors resulting from ground control $(\leq 0.1 \mathrm{~m})$, the rectification process $(\leq 0.3 \mathrm{~m})$, as well as the vertical accuracy of the resulting DTM $(\leq 0.2 \mathrm{~m})$ and the accuracy of the images based on the pixel resolution $(\leq 0.25 \mathrm{~m})$. The source of the rectification error $\left(e_{r}\right)$ for both dates of imagery is the standard deviation of the control point error within each block from the photogrammetric processing (Slama, 1980; Wolf and Dewitt, 2000). In the case of this study the value propagated through the uncertainty analysis is two standard deviations, to provide a 95\% confidence level. This assumes that the errors are non-systematic (random), and are normally distributed.

The vertical accuracy of the DTM $\left(e_{d}\right)$ is a function of the scale of the photographs, and hence the flying height and camera focal length, from which the DTMs are created. The DTM accuracy is estimated as $1 / 9000^{\text {th }}$ of the flying height of the aircraft carrying the camera system (Maune, 2001). Using standard statistics, the error, or variance, associated with the DTM model for each date is determined by:

$$
E_{t}=\left[\left(e_{g}\right)^{2}+\left(e_{r}\right)^{2}+\left(e_{d}\right)^{2}+\left(e_{p}\right)^{2}\right] 0.5
$$

where, $e_{g}=$ ground control error, $e_{r}=2$ standard deviations of the rectification error; $e_{d}=d t m$ error; $e_{p}=$ pixel resolution; and the subscript $t$ is a given time, or date, from which the data are derived. This error is translated to an uncertainty in volume by assessing the calculated error over the area within which the volume was calculated:

$$
\delta_{v t}=\left(E_{t} * A\right) / V_{t}
$$

Where $\mathrm{A}$ is the area over which the volume was calculated and $\mathrm{V}_{\mathrm{t}}$ is the volume calculated for a particular date. This equation produces a percent volume of the total calculated volume that is 
within the uncertainty range for that dataset. To determine the total in the volume change calculation, the uncertainties for the two dates are summed:

$$
\text { Total error }=\delta_{v_{t 1}}+\delta_{v_{t 2}}
$$

Given the maximum errors described above, the average error from the data source and processing is $0.5 \%$, almost a negligible amount. Therefore the error is not reported for the values provided in the discussion section .

\section{Discussion: Volume Change, Rates and Processes}

The results of the volumetric change analysis are shown in Tables $2 A, 2 B$, and $2 C$. The data provided include the total net volume loss to the nearshore, which is defined here as:

$$
L_{n t}=\left(L_{n a}+L_{b}\right)+G_{b}
$$

where, $L_{n t}=$ total net volume loss, $L_{n a}=$ net loss above the road grade; $L_{b}=$ loss below the road grade; $G_{b}=$ gain below the road grade. This equation assumes that the net of the material lost above the road grade is deposited (naturally or by excavation) below the road grade. The gain $\left(G_{b}\right)$ below the road grade is summed because the losses $\left(L_{n a}\right.$ and $\left.L_{b}\right)$ are negative. Table 2 also provides the surface area of each landslide complex over which the gains and losses were determined, and the rate at which material is lost to the nearshore for each of the three time periods.

The average loss rates for each of the three areas are: $-3.9 \mathrm{~cm} / \mathrm{yr}$ for Hurricane Point, -3.7 cm/yr for Big Slide-Pitkins, and -10.5 cm/yr for Grayslip. In both the Hurricane Point and Big Slide-Pitkins landslides, there was a net gain below the road grade during the period from1986 to 1993. Some of this gain may be anthropogenic, and some may be storage of material at the slope base in the form of debris fans from smaller, surficial flows and rock falls.

These rates represent the average loss over the 25-year period from 1976 to 2001. However,

they do not provide information on the highly episodic nature of large slope failures in the area. It is clear from assessing the loss data from the individual time periods (Table 2 and fig. 3) that the periods that include large El Niño years (1982-83 and 1997-98) account for the majority of the material lost. In both the Hurricane Point slide and the Big Slide-Pitkins area, there was no measurable loss of material to the nearshore in the period that did not include a large El Nino winter (1986-1993). This indicates that material deposited at the slope base during this time was stored there until large wave events removed both stored material and enough additional material 
Table 2A. Net loss and material loss rates for Hurricane Point.

\begin{tabular}{|cccc|}
\hline & $1976-1986$ & $1986-1993$ & $1993-2001$ \\
Total Net Loss $(\mathbf{m} 3)$ & $-19,000.3$ & $+64,252.2$ & $-233,974.0$ \\
Surface Area (m2) & $263,794.6$ & $263,660.2$ & $264,381.9$ \\
Loss/Area (m3/m2) & -0.07 & -- & -0.89 \\
Loss Rate (cm/yr) & -0.72 & -- & -11.06 \\
\hline
\end{tabular}

Table 2B. Net loss and material loss rates for Big Slide-Pitkins

\begin{tabular}{|cccc|}
\hline & $1976-1986$ & $1986-1993$ & $1993-2001$ \\
Total Net Loss (m3) & $-104,914.1$ & $+3,140.2$ & $-375,333.0$ \\
Surface Area (m2) & $353,888.04$ & $353,527.64$ & $351,092.14$ \\
Loss/Area (m3/m2) & -0.30 & -- & -1.07 \\
Loss Rate $(\mathbf{c m} / \mathbf{y r})$ & -3.0 & -- & -13.38 \\
\hline
\end{tabular}

Table 2C. Net loss and material loss rates for Grayslip

\begin{tabular}{|cccc|}
\hline & $1976-1987$ & $1987-1993$ & $1993-2001$ \\
Total Net Loss $(\mathbf{m} 3)$ & $-119,606.4$ & $-72,975.4$ & $-315,914.9$ \\
Surface Area (m2) & $205,886.7$ & $205,883.260$ & $204,852.0$ \\
Loss/Area (m3/m2) & -0.58 & -0.35 & -1.54 \\
Loss Rate $(\mathbf{c m} / \mathbf{y r})$ & -6.46 & -5.91 & -19.28 \\
\hline
\end{tabular}




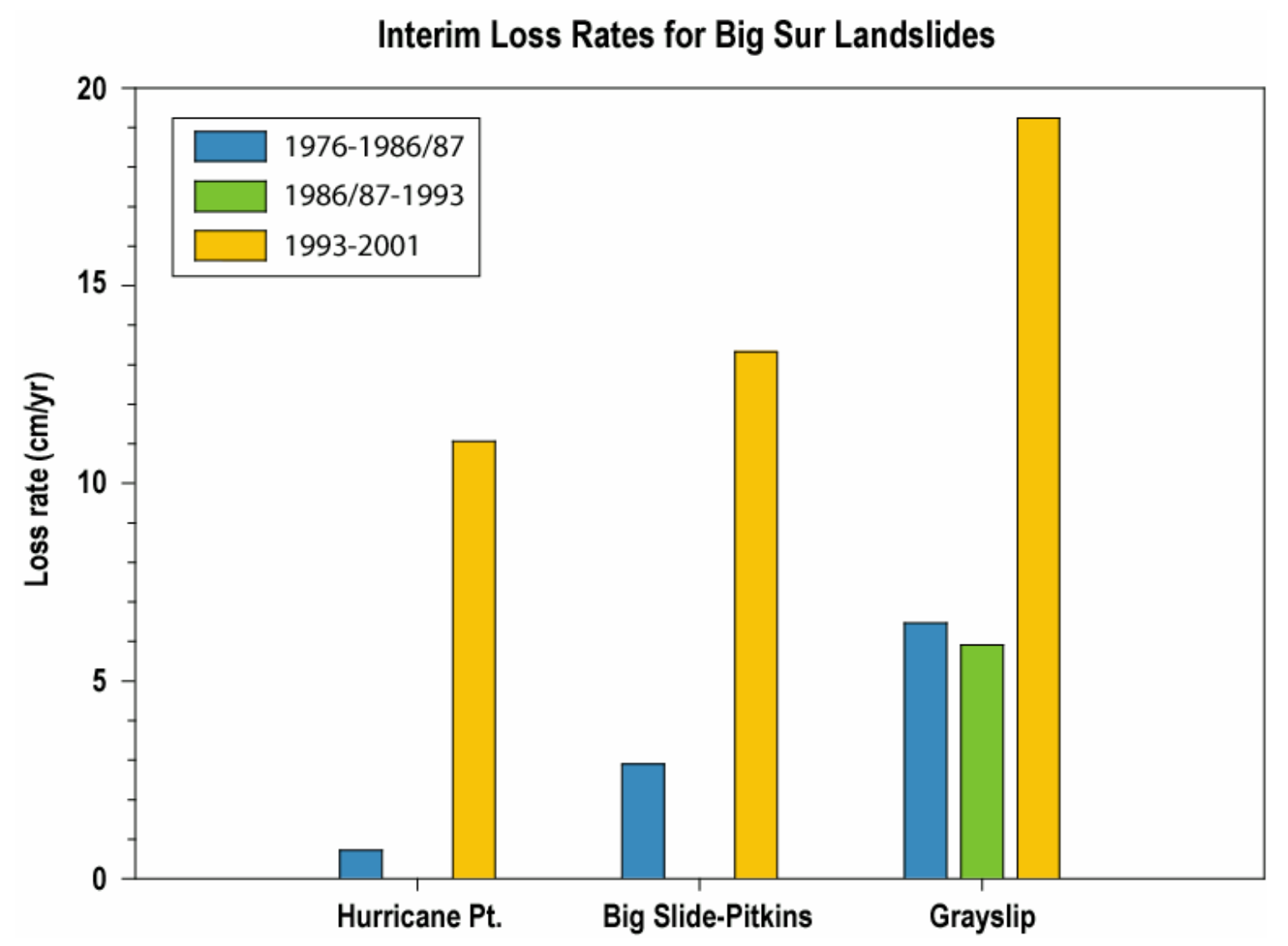

Figure 3. Bar graph showing the interim ( decadal) loss rate of material to the nearshore for each of the three landslide sites analyzed.

to undercut the slope base and induce further large-scale failure. This process can be seen in the gain/loss distribution maps of figure $4 A, 4 B$, and $4 C$. These maps show orthophotographs draped on terrain models, with the distribution of measured material loss and gain for each time period shown in red (loss) and gain (blue). The maps, in combination with the data shown in Table 2 and figure 3, provide a decadal-scale perspective on the rates and processes by which these large-scale landslides deliver material to the nearshore.

\section{Hurricane Point}

This was not an area of chronic sliding in the history of the road (JPR Historical Consulting Services, 2001) until movement on the slide in 1999 resulted in closure or partial closure (one lane) of the highway for four months while the road was repaired and the slope stabilized. The slide mass undercut the road and as a result the repair involved moving the entire highway landward. As mapped by Caltrans (unpublished data), Hurricane Point is a rotational landslide, with the slide plane exposed at the base of the slope. The slide appears to be fault 
controlled, initiating at the contact between Sur Complex of Hall (1991) metamorphic rocks and the deformed sediments of the Pismo Formation. The net volume loss analysis conducted as part of this study shows that the loss rates were negligibly small prior to the 1993-2001 time period. In the earliest period of this analysis (1976-1986), the loss rate was less than a centimeter a year and this material was generated primarily from surficial debris flows and block falls below the road grade, based on the evidence of widespread gullying visible in the imagery and DTMs, as well as the material loss/gain distribution shown in figure $4 A$. In the time period from 1986-1993, there was no measured net loss from this landslide complex to the nearshore. The distribution map shows material accumulation at the base of the slope. While there is not measured loss higher on the slope to account for the accumulation, there is evidence of a series of lower slope gully complexes that merge to discrete depositional areas; the losses from the individual gullies and their head sources may be smaller than our analysis can confidently map, but if a number of these merge into a single debris fan, it could account for the measured accumulation. The distribution of the accumulation zones supports this hypothesis.

The majority of the net loss from the Hurricane Point landslide was measured in the period from 1993-2001. The loss rate increased to $11 \mathrm{~cm}$ per year, as a result of the total net loss of over $230,000 \mathrm{~m}^{3}$ of material. While it is assumed that the majority of this material was mobilized during the initial failure in 1999, loose, incoherent deposits on the slope and at the slope base from the 1999 failure probably continue to erode into the nearshore environment, resulting in a higher rate now than pre-1999.

\section{Big Slide-Pitkins Curve}

This stretch of the Big Sur coast is a foci of active, chronic landsliding. The area is made up of two separate landslide complexes, Big Slide to the northwest and Pitkins curve to the southeast (fig. 2B). A relatively stable area separates the two complexes although more recent slope failures on the Pitkins Curve slide suggest the two complexes may be merging. Both of these slides have been historically active; slides and road damage are documented back to 1952 (JPR Historical Consulting Services, 2001). Most recently, Big Slide failed catastrophically in the winter of 1998. The road was repaired and the slope locally stabilized; however the slide complex continues to creep. The gain/loss distribution map of this area (fig. 4B) indicates that this slide complex has been very active throughout the time period of this study, and was more active than the Pitkins Curve landslide during 1976-1986.

The Pitkins Curve slide to the southeast is currently one of the most active sites along the Big Sur coast. The steep slope most recently became highly active in the winter of 2000 , although historical documentation shows a long history of landslides that have blocked or damaged the road. In 2000, after a series of large winter storms, the roadway was undercut by what was mapped as a rotational slide with the head scarp just above the road grade. The 
highway was relocated inland and the slope above the road stabilized. However, the excavation apparently further destabilized the slope above the road grade and there have been numerous post-construction failures over the past several years. While these processes are more localized with respect to the highway grade, there is evidence from the distribution map (fig. $4 B$ ) that the entire hillslope, up to the first ridgeline, is creeping at a rate of nearly $0.4 \mathrm{~m} / \mathrm{yr}$. The entire landslide area including Big Slide and Pitkins Curve is mapped as Quaternary landslide deposits, although locally the material within road cuts can be identified as highly sheared metavolcanic rocks of the Franciscan Complex overlain by several meters of colluvium.

Total net loss rates along the Big Slide-Pitkins area are substantially higher than at Hurricane Point. This is expected due to the lithological variation between the two locales. The loss rates for the Big Slide-Pitkins landslides from1976-1986 are over four times greater than at Hurricane Point. During the middle time period (1986-1993) there was no measured net loss of material to the nearshore indicating, similarly to Hurricane Point, that this was a time during which accumulated material was stored along the lower slope and slope base. The distribution map shows there was little overall movement of material within either complex during this period, with the exception of the very southern portion of the Pitkins Curve area called "Rainrocks" (fig. $2 B$ ). This steep bedrock promontory was continually shedding rock debris onto the roadway below and was finally covered with rock net in 2000 to prevent further damage to the highway.

From 1993 to 2001, the total net loss rates increased dramatically to $13.38 \mathrm{~cm} / \mathrm{yr}$. The large increase is attributed to both the intense storms bringing both increased rainfall and large waves, and destabilization and remobilization of slope material from both natural and anthropogenic slope activity.

\section{Grayslip}

The Grayslip landslide is another chronically active slope failure site along the Big Sur coast. The long-term history of this slide is not well documented but aerial photo analysis and geologic mapping suggest that it has been active over the past century and it is mapped in Quaternary landslide deposits, indicating a much longer history of failure. Of the three sites investigated in this analysis, Grayslip is the most classic, rotational slide. The original head scarp, active head scarp, transverse cracks, and toe deposits can all be readily identified on aerial photographs (fig. $4 C)$.

Similar to the other landslide sites studied in this analysis, Grayslip is mapped within existing Quaternary landslide deposits (Wills and others, 2001). The underlying bedrock is sheared metavolcanic rocks of the Franciscan Complex, and the total net loss rate to the nearshore is higher here than at any of the studied landslide sites due primarily to the extremely weak lithology of the slope-forming rock (fig. 3). Coast Highway 1 runs through the center of the lower potion of the landslide, and the slope above the road grade has been active throughout the time 
period of this analysis. A well-defined active headscarp developed on the upper northern slope sometime during the 1976-1987 period (see fig. 4C). Like the other landslide sites, the greatest total net loss occurred in the time periods that contained large El Niño events (1976-1987 and 1993-2001), and the new headscarp most likely became active due to the increased precipitation during the 1982-83 El Niño winter. The net loss rate during this time was $6.5 \mathrm{~cm} / \mathrm{yr}$ and dropped only slightly in the following time period to $\sim 6 \mathrm{~cm} / \mathrm{yr}$ (fig. 3). The loss rate increased three-fold during the most recent period, to over $19 \mathrm{~cm} / \mathrm{yr}$, the highest measured loss rate recorded in this study. The distribution maps also indicate that the active portion of the slide migrated from north to south within the complex (fig. 4C). The total volume of material lost to the nearshore (see Table 2) between 1993 and 2001 was over 315,000 $\mathrm{m}^{3}$.

\section{Conclusions}

This study was undertaken to supplement an earlier analysis that provided regional information on the volume of material that is lost to the nearshore over the long-term (50-years) along the entire Big Sur coast (Hapke, 2005; Hapke and others, 2004). While the earlier analysis provided crucial baseline data regarding sediment volumes, it did not endeavor to examine the rates and processes by which material is delivered to the nearshore environment. This analysis quantifies the net loss rate at three specific landslide sites along the Big Sur coast and describes the processes by which the material is transported. For each of the three landslides sites (Hurricane Point, Big Slide-Pitkins, and Grayslip), four dates of aerial photographs were processed using photogrammetric techniques to produce orthophotomosaics and DTMs. The models were imported into a GIS and differenced to provide a 25 -year time series of the net volume loss and a map of the material loss/gain distribution.

The net loss rates vary substantially along the coast and appear to be related to both the local lithology and climatic forcing. For example, the overall loss rates at Hurricane Point, which is primarily within the metamorphic rocks of the Sur Complex of Hall (1991) are the lowest of the three sites.

The highest loss rates are within the weak Franciscan Complex rocks at the central and southern sites (Big Slides-Pitkins Curve and Grayslip landslides, respectively). Historical 


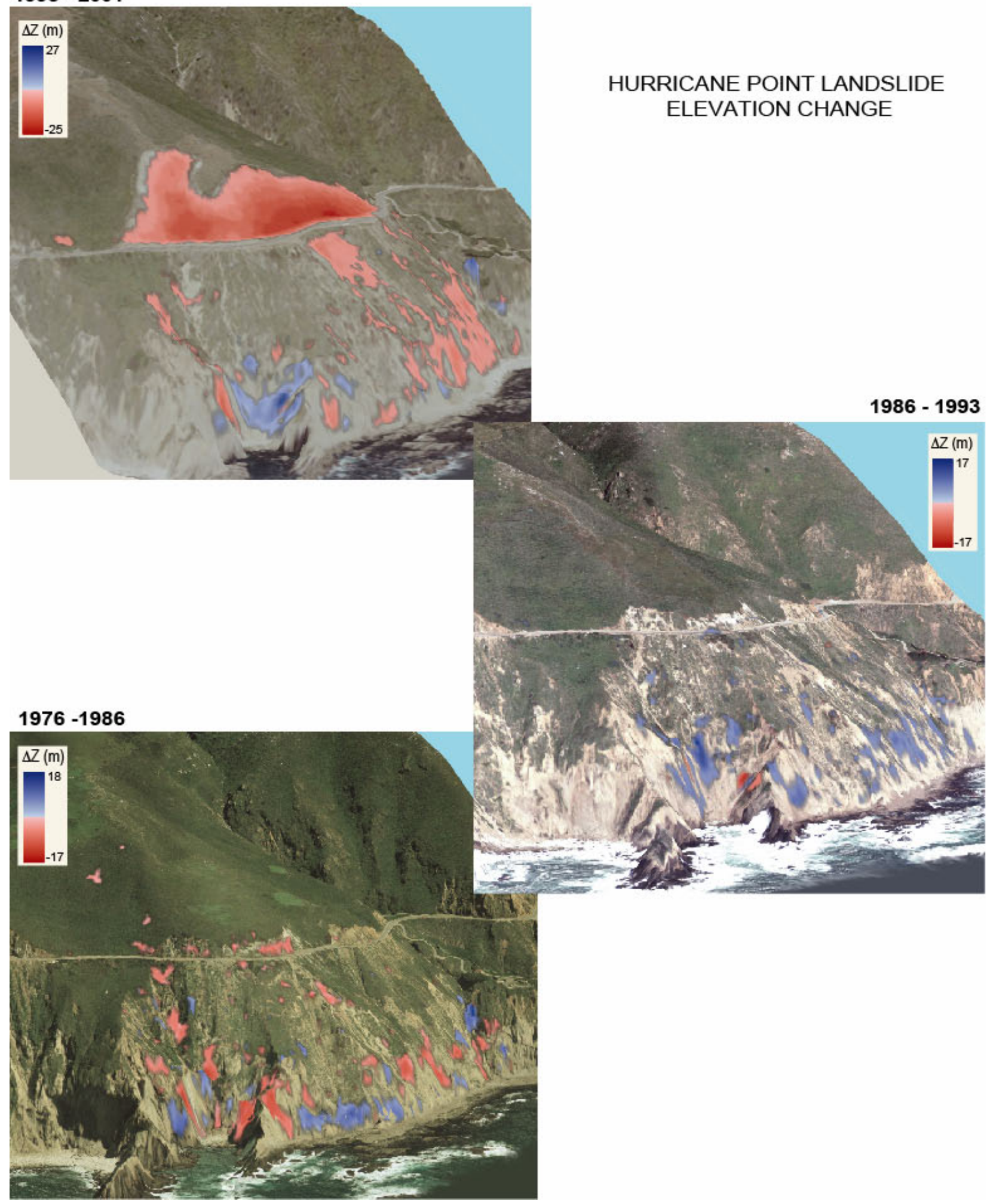

Figure 4A. The loss/gain distribution maps for Hurricane Point show the areas for each analysis period where there has been a loss (reds) or gain (blues) of material within the landslide complex. These distribution maps are derived by differencing topographic models for the time periods indicated on each photo. The distribution maps shown on orthophotograph draped on the DTM for each period. 
BIG SLIDE/PITKINS CURVE LANDSLIDE ELEVATION CHANGE
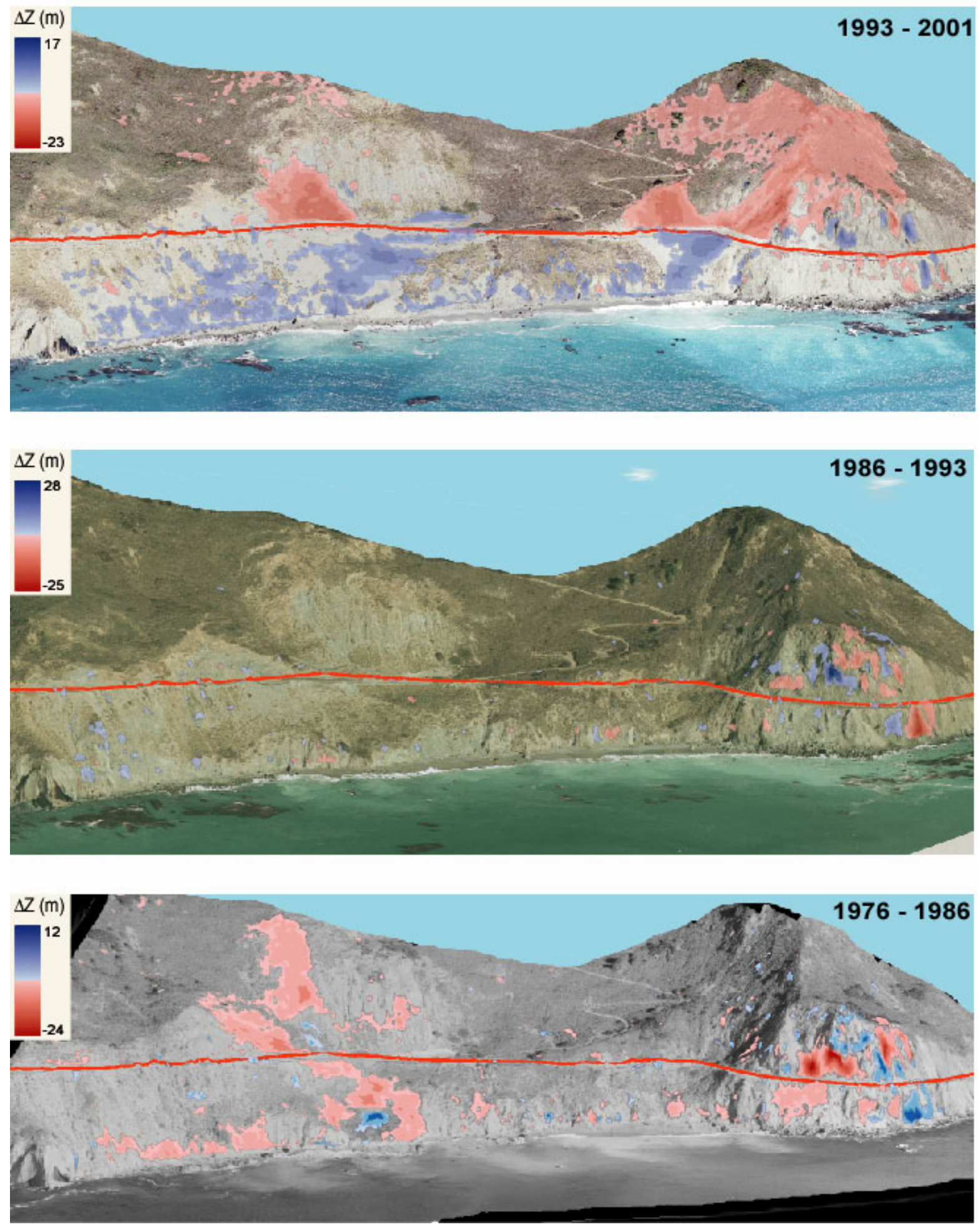

Figure $4 B$. The loss/gain distribution maps for Big Slide-Pitkins show the areas for each analysis period where there has been a loss (reds) or gain (blues) of material within the landslide complex. These distribution maps are derived by differencing topographic models for the time periods indicated on each photo. The distribution maps shown on orthophotos draped on the DTM for each period. 


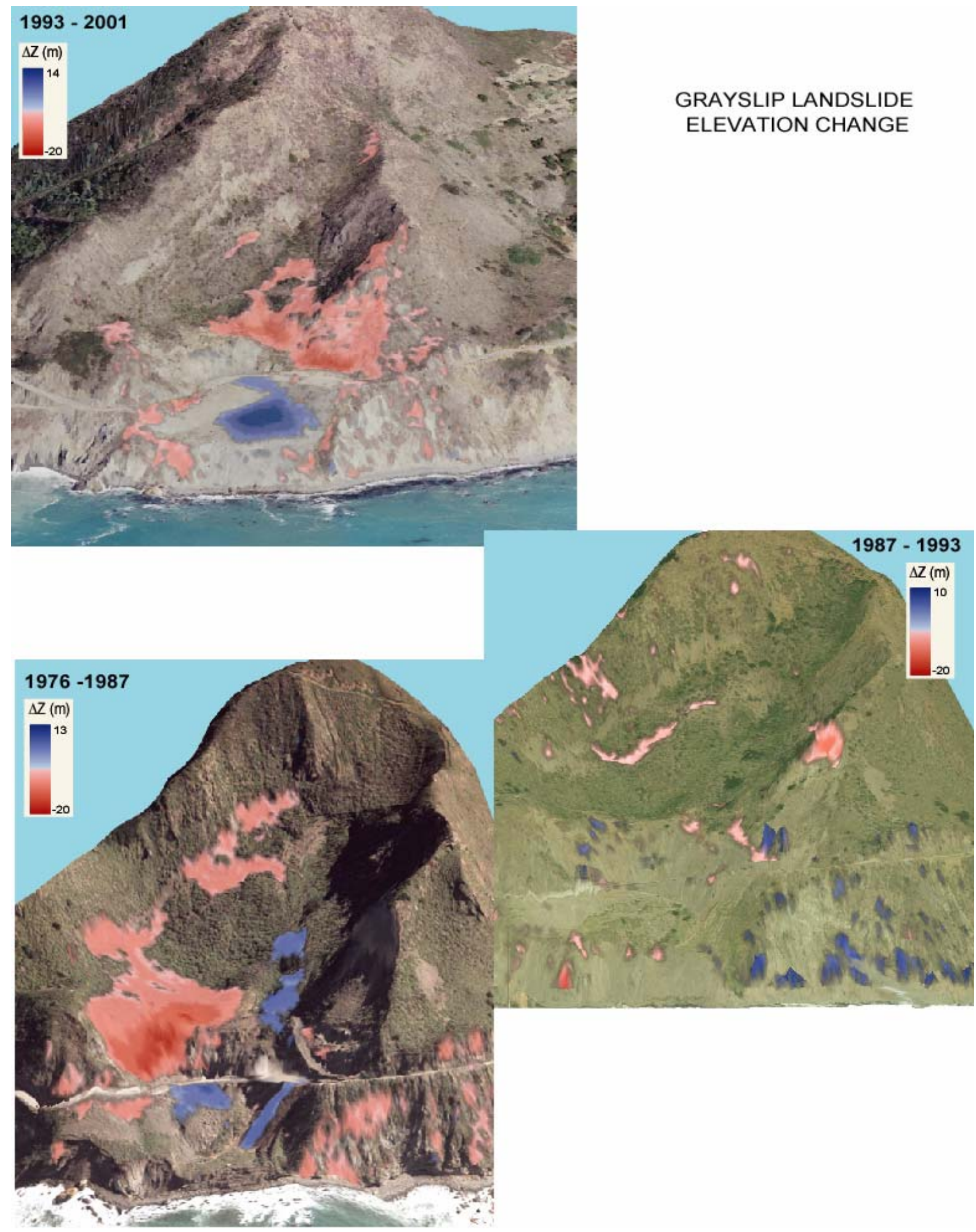

Figure 4C. The loss/gain distribution maps for Grayslip show the areas for each analysis period where there has been a loss (reds) or gain (blues) of material within the landslide complex. These distribution maps are derived by differencing topographic models for the time periods indicated on each photo. The distribution maps shown on orthophotos draped on the DTM for each period. 
documentation indicates that landslide activity greatly increases during large El Niño years (i.e. 1940-41, 1982-83, and 1997-98) (JRP Historical Consulting Services, 2001). The time periods within this analysis that contain two of the largest recorded El Niño events also have greatly increased net loss rates, especially the period containing the 1997-98 El Niño, where the loss rates increased by $13 \mathrm{~cm} / \mathrm{yr}$ from the earlier non-El Niño period (1986/87 - 1993). An exception is at Hurricane Point, where although the net loss rates increased substantially in the final time period of this analysis, the landslide occurred in 1999, a year after the large El Niño event of 1997-98. In addition, although rates at the two southern landslide sites were higher during the earliest period (1976-1986/87) than from 1986/87-1993, the acceleration of the loss rates during the final period (1993-2001) is substantially higher than either of the previous periods, suggesting that the 1997-98 El Niño had a much greater impact on slope destabilization. In all three study sites, movement on large deep-seated landslide were responsible for mobilizing material, and depositing it on the lower slope or at the slope base. Subsequent shallow failures in the loose material and wave erosion at the base of the slope resulted in loss of material to the nearshore environment.

The data and analysis presented in this study are intended to provide baseline information to assist Caltrans and the MBNMS in understanding how the pulses of material influx along the Big Sur coast vary spatially and through time, and what factors are affecting the influx rates. The three study sites were chosen to be representative of chronic slide areas that have impacted both the maintenance of Coast Highway 1 and the nearshore environment of the MBNMS.

\section{Acknowledgements}

We would like to thank Aileen Loe of Caltrans District 5 for all her coordination efforts and for making this research project possible. Tom Reiss of the USGS provided expert assistance and guidance in the field during the collection and subsequent processing of ground control point data. Mimi D'Iorio, Amy Foxgrover and Shawn Higgins of the USGS provided valuable GIS help. The Caltrans Big Sur Coastal Highway Management Plan and the USGS Coastal and Marine Geology Program funded this research.

\section{References}

Bailey, E.H., Irwin, W.P., and Jones, D.L., 1964, Franciscan and related rocks and their significance in the geology of western California: California Division of Mines and Geology Bulletin 183, $177 \mathrm{p}$. 
Dibblee, T.W., Jr. 1974, Geologic Maps of the Monterey, Salinas, Gonzales, Point Sur, Jamesburg, Soledad and Junipero Serra quadrangles, Monterey County, California: U.S. Geological Survey Open-File Report 74-1021, scale 1:62,500, 1 sheet.

Hall, C.A., Jr., 1991, Geology of the Point Sur-Lopez Point region, Coast Ranges, California: A part of the Southern California allochthon: Geological Society of America Special Paper 266, $40 \mathrm{p}$.

Hapke, C.J., 2005, Estimated material yield from coastal landslides based on historical digital terrain modeling, Big Sur, California: Earth Surface Landforms and Processes, v. 30, p. 679-697.

Hapke, Cheryl J., Green, Krystal R., and Dallas, Kate, 2004, Map Showing Estimated Sediment Yield from Coastal Landslides and Active Slope Distribution Along the Big Sur Coast, Monterey and San Luis Obispo Counties, California, USGS Scientific Investigations Map 2852, 1 sheet, 1:67,500.

James, E.W., and Mattinson, J.M., Metamorphic history of the Salinian block: An isotopic reconnaissance, in Ernst, W.G., ed., Metamorphism and crustal evolution of the western United States; Rubey Volume 7, Englewood Cliffs, New Jersey, Prentice-Hall, p.938-952.

JPR Historical Consulting Services, 2001, A history of road closures along Highway 1, Big Sur, Monterey and San Luis Obispo Counties, California, (http://www.dot.ca.gov/dist05/projects/bigsur/news.htm).

Maune, D.F., Kopp, S.M., Crawford, C.A., and Zervas, C.E., 2001, Introduction: Digital Elevation models, in Maune, D.F., ed., Digital Elevation Model Technologies and Applications: The DEM Users Manual: Bethesda, Maryland, American Society of Photogrammetry and Remote Sensing, p. 1-34.

Ross, D.C., 1976, Reconnaissance geologic map of the pre-Cenozoic basement rocks, northern Santa Lucia Range, Monterey County, California: U.S. Geological Survey Miscellaneous Field Studies Map MF-750, 1 sheet.

Slama, C., ed., 1980, Manual of Photogrammetry: Falls Church, VA, American Society of Photogrammetry, $1056 \mathrm{p}$.

Wills, C.J., Manson, M.W., Brown, K.D. Davenport, C.W., and Domrose, C.J., 2001, Landslides in the Highway 1 Corridor: Geology and Slope Stability Along the Big Sur Coast, Report to the Coast Highway Management Plan Caltrans District 5, 29 p.

Wolf, P.R. and Dewitt, B.A., 2000, Elements of Photogrammetry with Applications in GIS: Boston, McGraw Hill, $3^{\text {rd }}$ ed., 608 p. 